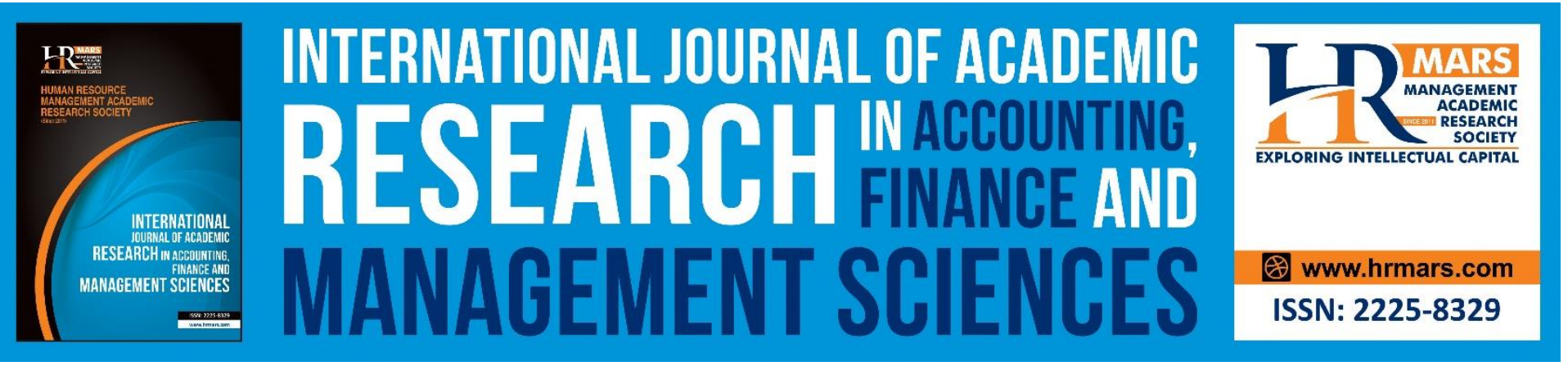

\title{
The Effect of Firms Characteristics on Corporate Risk Disclosure: Empirical Evidence from Amman Stock Exchange
}

\author{
Malek Hamed Alshirah, Azhar Abdul Rahman, Ifa Rizad Mustapaand and \\ Ahmad Farhan Alshira'h
}

To Link this Article: http://dx.doi.org/10.6007/IJARAFMS/v10-i3/8083

DOI:10.6007/IJARAFMS /v10-i3/8083

Received: 11 June 2020, Revised: 20 July 2020, Accepted: 23 October 2020

Published Online: 17 November 2020

In-Text Citation: (Alshirah, Abdul Rahman, Mustapa, and Alshirah, 2020)

To Cite this Article: Alshirah, M. H., Abdul Rahman, A., Mustapa, I. R., and Alshira'h, A. F. (2020). The Effect of Firms Characteristics on Corporate Risk Disclosure: Empirical Evidence from Amman Stock Exchange. International Journal of Academic Research in Accounting, Finance and Management Sciences. 10(3), 336348.

\section{Copyright: (C) 2020 The Author(s)}

Published by Human Resource Management Academic Research Society (www.hrmars.com)

This article is published under the Creative Commons Attribution (CC BY 4.0) license. Anyone may reproduce, distribute, translate and create derivative works of this article (for both commercial and non-commercial purposes), subject to full attribution to the original publication and authors. The full terms of this license may be seen

at: http://creativecommons.org/licences/by/4.0/legalcode

Vol. 10, No. 3, 2020, Pg. 336 - 348

http://hrmars.com/index.php/pages/detail/IJARAFMS

JOURNAL HOMEPAGE

Full Terms \& Conditions of access and use can be found at http://hrmars.com/index.php/pages/detail/publication-ethics 


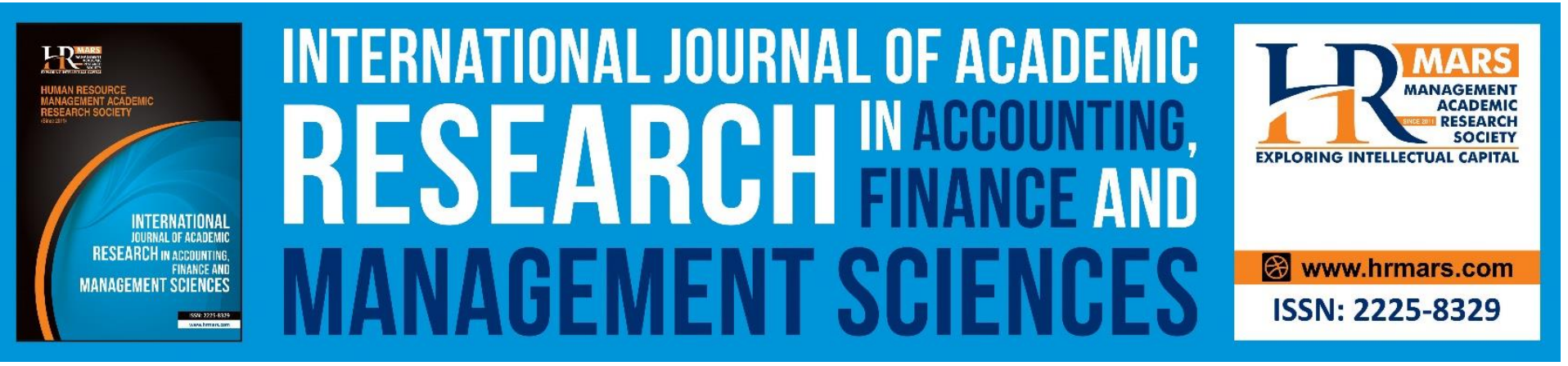

\title{
The Effect of Firms Characteristics on Corporate Risk Disclosure: Empirical Evidence from Amman Stock Exchange
}

\author{
Malek Hamed Alshirah¹, Azhar Abdul Rahman², Ifa Rizad \\ Mustapaand ${ }^{3}$ and Ahmad Farhan Alshira' ${ }^{4}$ \\ ${ }^{1}$ Accounting Department, Faculty of Economics \& Administrative Science, Al al-Bayt University \\ ${ }^{2.3}$ School of Accountancy, College of Business, Universiti Utara Malaysia, Sintok, Malaysia \\ ${ }^{4}$ Faculty of Administrative Sciences and Financial, Department of Accounting, Irbid National \\ University
}

Email:shraamalek@gmail.com,azhar258@uum.edu.my, ifarizad@uum.edu.my, alshraah.ahmad@yahoo.com

\begin{abstract}
This paper measures the extent of corporate risk disclosure and the relationship of a set of firms characteristics (firm size, type of sector, leverage, profitability, and liquidity) on the level of risk disclosure in Jordan. The measurement of risk disclosure is based on published data of sampled Jordanian firms listed on Amman Stock Exchange using the content analysis approach. The findings indicate that large firms, industrial firms, and firms with a high level of leverage and profitability disclose more risk information than others do. However, the rate of liquidity showed a negative effect on the level of risk disclosure. The findings of this study also enhance the understanding of the corporate risk disclosure environment in Jordan as an example of the emerging markets in the Middle East. The study contributes to disclosure studies by being the first study to explore the relationship between the risk disclosure level and firm characteristics in Jordan. In addition, this study provides clear insight into the determinants of risk disclosure to the stakeholders of the Jordanian companies. Keywords: Risk Disclosure, Firm Characteristics, Content Analysis, Jordan.
\end{abstract}

\section{Introduction}

In the aftermath of the corporate scandals and financial crises, regulators and policymakers have confirmed that a lack of transparency and inadequate risk reporting were important factors contributing to the financial crises (Aryani \& Hussainey, 2017; Ntim, Lindop, \& Thomas, 2013). These issues have led to raise a significant concern regarding corporate risk disclosure, and the stakeholders' needs to improved risks reports have increased (Cordazzo, Papa, \& Rossi, 2017; Uddin \& Hassan 2011; Zeghal \& Aoun, 2016), in order to allows outsider investors to assess a company's current risks and judge future prospects to accurately assess future risk (Linsley \& Shrives, 2006). 
INTERNATIONAL JOURNAL OF ACADEMIC RESEARCH IN ACCOUNTING, FINANCE AND MANAGEMENT SCIENCES

Vol. 10, No. 3, 2020, E-ISSN: 2225-8329 @ 2020 HRMARS

Corporate risk disclosures are fundamental for providing transparent information and developing the confidence of stakeholders (Abraham \& Cox, 2007; Beretta \& Bozzolan, 2004; Cabedo \& Tirado, 2004; Hassan 2009; Linsley \& Shrives, 2006). Furthermore, risk information stand out as a key factor that helps investors to make sound investment decisions by providing a clear explanation and more understanding of risk elements and the complexity of the business environment (Lajili, 2009; Nahar, Azim, \& Jubb, 2016). Therefore, they should require more transparent risk disclosure to ensure that the presented information reflect the exact position of the firm.

Although the huge amount of risks surrounding the business of firms over the world, there is a gap of risk information between companies and their shareholders, where, the companies release little about the risk information in annual reports (Schrand \& Elliott, 1998). Furthermore, existent research refer to large variations of the level of risk between companies. Therefore, understanding what are the different attributes between the firms that disclose a high level of risk information and others that disclose lower level or on the other word, what is the relationship between these attributes and the level of risk disclosure is a critical question. However, there is a scarcity of research that investigate this relationship, particularly in developing countries. Therefore, the current study contributes by exploring the effect of firm's characteristics on risk disclosure level in Jordan as an example of the developing countries, where, there is a shortage of research on this topic.

The remainder of the paper proceeds as follows: section 2 discusses develops the hypotheses; section 3 outlines the research design and methodology; section 4 discusses empirical analysis; and section 5 offers conclusions.

\section{Hypotheses Development Firm Size}

Company size would be as an important variable to explain the variation in corporate disclosure (AlShammari, 2014). Large company is characterized by more complex and more various operations, which would result higher risk leading to higher asymmetric information (Jensen \& Meckling, 1976; Khlif \& Hussainey, 2016; Watts \& Zimmerman, 1986). Hence, the rationale is large companies have great incentives to utilize corporate risk disclosure as a means of reducing information asymmetry and maintaining their reputation and legitimacy (Al-Shammari, 2014; Mokhtar \& Mellett, 2013; Oliveira, Lucia, \& Craig, 2011). Consequently, larger firms are expected to provide a greater level of risk-related information to explaining their level of returns than smaller corporations and, therefore, reduce political sensitivity and improve investor confidence (Hassan, 2009). Based on signalling theory, larger firms often depend on external financing Larger companies have higher resources than smaller companies and better asset quantity (Linsley, \& Shrives, 2002). Therefore, they are encouraged to provide more corporate risk disclosure in order to transmit a good signal to stakeholders concerning their ability in managing risk (Al-Shammari, 2014; Elzahar \& Hussainey, 2012). In the context of risk disclosure research, Abraham and Cox (2007), Amran, Bin and Hassan (2009), Al-Shammari (2014), Konishi and Ali (2007), Mohobbot (2005) and Shrives and Linsley (2003) all discovered a positive connection between firm's size and risk disclosure. Conversely, Hassan (2009) documented that the relationship between the two variables is insignificant, and Aljifri and Hussainey (2007) revealed an insignificant correlation between firm size and the corporate disclosure of forward-looking information in UAE firms. Hence, based on signalling theory, we formulate the first hypothesis as follows:

$\mathrm{H} 1$ : There is a positive relationship between Firm Size and the level of risk disclosure. 
INTERNATIONAL JOURNAL OF ACADEMIC RESEARCH IN ACCOUNTING, FINANCE AND MANAGEMENT SCIENCES

Vol. 10, No. 3, 2020, E-ISSN: 2225-8329 @ 2020 HRMARS

\section{Type of Sector}

Signalling theories have proposed the effect of industry variable on disclosure (Inchausti, 1997; Rajab \& Handley-Schachler, 2009). The type of sector is one possible explanatory variable for risk disclosure level in financial reporting in which different and unique constraints of business environments might affect different industries. As a result, levels of corporate risk disclosure might be different among sectors depending on the extent of risk exposure of each sector (Elzahar \& Hussainey, 2012). Thus, the type of sector may have an important effect on the nature and magnitude of information, which are disclosed by firms (Rajab \& Handley-Schachler, 2009).

The findings on the association between sector type and disclosure have shown mixed results. Cooke (1992) discovered significant linkages between the type of industry and level of disclosure in Japanese manufacturing companies. Rajab and Handley-Schachler (2009) revealed that industry type was significantly and positively related to the risk information that companies disclose. Mangena and Pike (2005) reported a significant correlation between type of sector and corporate disclosure. Meanwhile, Beretta and Bozzolan (2004) found no significant association between the industry type and corporate disclosure. Similarly, Aljifri and Hussainey (2007) revealed that sector type had an insignificant correlation with the disclosure level of forward-looking information in the UAE companies. Based on these arguments, we set our hypothesis as follows:

H2: There is a positive relationship between Type of Sector and the level of risk disclosure

\section{Leverage}

Highly leveraged firms are likely to have higher agency cost, hence companies should disclose greater information to meet the needs of creditors (Jensen \& Meckling, 1976). Based on signalling theory, managers have a tendency to give more corporate risk information to transmit a positive signal to debt holders with respect to the ability of firm to meet their obligations (Naser, Al-Khatib, \& Karbhari, 2002). Furthermore, companies with high leverage attempt to prove to their creditors that they will not fail to meet their agreements, and they therefore disclose more voluntary information. Prior literature has documented leverage lead to enhance the disclosure level, Eng and Mak (2003), Ho and Wong (2001) found that leverage was positively connected with the voluntary disclosure level. The correlation between leverage and risk disclosure practices in previous studies was found inconsistent. For example, Linsley and Shrives (2006), Abraham and Cox (2007), Konishi and Ali (2007), Rajab and Handley-Schachler (2009), Elzahar and Hussainey (2012), Miihkinen (2012) and Nitm et al. (2013) found an insignificant relationship between leverage and risk disclosure. Meanwhile, Hassan (2009) and Taylor, Tower and Neilson (2010) found a positive relationship between the two variables. In order to examine this, we formulate the hypothesis as follows:

H3: There is a positive relationship between Leverage and the level of risk disclosure.

\section{Profitability}

Companies that are better at risk management will have higher levels of profitability (Konishi \& Ali, 2007). Agency theory expects that managers of companies with high profitability would tend to provide more risk information in the in order to justify their present performance to the shareholders (Elzahar \& Hussainey, 2012). Furthermore, based on signaling theory, profitable firms have the incentive to distinguish themselves from less successful firms, thus, the disclosures are one way to achieve this (Mousa \& Elamir, 2013). Along with that, Barako, Hancock and Izan (2006), Chen, Chen 
INTERNATIONAL JOURNAL OF ACADEMIC RESEARCH IN ACCOUNTING, FINANCE AND MANAGEMENT SCIENCES

Vol. 10, No. 3, 2020, E-ISSN: 2225-8329 ๑ 2020 HRMARS

and Chengf (2008), Ho and Wong, (2001) argued that firms which have been successful will report this success than those that have losses to report. Thus, they disclose more voluntary information. Some studies have shown that there is a significant correlation between profitability and corporate risk disclosure. Mousa and Elamir (2013) claimed significant associations are reported between the quantity of CRD and firm profitability. Deumes and Knechel (2008) argued profitability were positively associated with risk disclosure. Meanwhile, Konishi and Ali, 2007 found insignificant relationship between risk disclosure and profitability. Similarly, Elzahar and Hussainey (2012) showed statistically insignificant impact of profitability on corporate risk disclosure. Meanwhile, Taylor, Tower and Neilson (2010) found no significant relationship between risk disclosure and profitability. Based on the above argument, current study assumes firm profitability as a possible contributor to firms' risk disclosure practices. Therefore, we hypothesize that:

H4: There is a positive relationship between profitability and the level of risk disclosure.

\section{Liquidity}

Based on signaling theory, the managers of companies will disclose extra information in case the liquidity are high to distinguish their capability in managing risk of liquidity from other managers in other companies having less liquidity. Alshammari 2014 found significant association between disclosure levels and liquidity. On the other hand, Elzahar and Hussainey (2012) found insignificant relationship between the two variables. Based on signaling theory and prior risk reporting studies, the following hypothesis is formulated:

H5: There is a positive relationship between liquidity and the level of risk disclosure.

\section{Methodology}

\section{Sample}

The sample of this study is Jordanian listed companies over a four year (2014 to 2017), because they are considered the most important sources that contribute in an increase of GDP in Jordan (ASE, 2017; Moumen, Othman, \& Hussainey, 2016). The ASE has divided Jordanian listed firms to three sectors: the financial sector, industrial sector and services sector. The current study selected the industrial and services sectors for study, which were 56 and 49 firms respectively in 2017 (ASE, 2017). 11 firms were excluded given data unavailability and other constraints. Firms in the financial sector have been excluded as they have different codes of corporate governance that the Jordanian Central Bank and the Insurance Commission have issued (Al-Akra et al., 2009).

\section{Dependent Variable and Content Analysis}

Content analysis method has been adopted for this research because this study aims to examining the level or nature of disclosure regardless the quality of corporate risk disclosures (Amran et al., 2009; Elzahar \& Hussainey, 2012; Linsley \& Shrives, 2006; Mokhtar \& Mellett, 2013). In addition, the current study used sentences as a coding unit because a word is the smallest unit in a sentence and cannot clearly convey an idea or message (Amran et al., 2009; Aryani \& Hussainey, 2017; Ivers, 1991; Linsley \& Shrives, 2006; Milne \& Adler, 1999; Mokhtar \& Mellett, 2013).

The broad definition of Linsley and Shrives (2006) were adopted in this study following the example of numerous risk disclosure researches (e.g., Abraham \& Cox, 2007; Ali \& Taylor, 2014; Amran et al., 2009; Elshandidy, Fraser, \& Hussainey, 2013; Elzahar \& Hussainey, 2012; Linsley \& Shrives, 2006; Mokhtar \& Mellett, 2013) to identify the risk-related sentences which inform the reader if "any 
INTERNATIONAL JOURNAL OF ACADEMIC RESEARCH IN ACCOUNTING, FINANCE AND MANAGEMENT SCIENCES

Vol. 10, No. 3, 2020, E-ISSN: 2225-8329 @ 2020 HRMARS

opportunity or prospect, or of any hazard, danger, harm, threat or exposure, that has already impacted upon the company or may impact upon the company in the future or of the management of any such opportunity, prospect, hazard, harm, threat or exposure" (Linsley \& Shrives, 2006, p.388). Moreover, this current study adopted and replicated a set of decision rules which developed by Linsley and Shrives (2006) to distinguish the risk information in the annual reports from other (see Appendix B). Afterward, to prove the validity of coding processes of risk disclosure, this study employs risk categories proposed by model of Linsley and Shrives (2006) and used in many previous risk disclosure literature (e.g., Amran et al., 2009; Elzahar \& Hussainey, 2012; Moumen, Othman, \& Hussainey, 2015; Moumen et al., 2016) (see Appendix A). This study calculated a final risk disclosure score for each firm by gathering the number of risk-related sentences exists in the annual reporting of Jordanian firms (Elzahar \& Hussainey, 2012).

\section{Models of the Study}

This study used following multiple regression modal to investigate the influence of firm characteristics on the level of corporate risk disclosure.

$\mathrm{CRD}_{\text {it }}=\beta 0+\beta 1 \mathrm{SIZE}_{i \mathrm{t}}+\beta 5 \mathrm{SCTR}_{\text {it }}+\beta 6 \mathrm{LEVER}_{\text {it }}+\beta 1 \mathrm{PROF}_{\text {it }}+\beta 1 \mathrm{LIQD}_{\text {it }}+\varepsilon$ it

Definitions of all independent used in the current analysis are presented in Table 1.

\section{Table 1}

Measurement of Variables

\begin{tabular}{|c|c|c|}
\hline Acronym & Variables & Measurement \\
\hline CRD & $\begin{array}{l}\text { Corporate Risk } \\
\text { Disclosure }\end{array}$ & $\begin{array}{l}\text { Measured by number of risk-related sentences exist in the } \\
\text { annual reports of Jordanian companies. }\end{array}$ \\
\hline SIZE & Company Size & Measured by natural log of total assets. \\
\hline SECTR & Type of Sector & $\begin{array}{l}\text { Classified into industrial or services sector, measured by } \\
\text { dummy variable, } 1 \text { if companies belong to an industrial sector, } \\
0 \text { otherwise. }\end{array}$ \\
\hline LEVER & Leverage & Measured by total debt to total assets. \\
\hline PROF & Profitability & Measured by return on assets. \\
\hline LIQD & liquidity & Measured by Current assets on current liabilities. \\
\hline
\end{tabular}

\section{Results}

\section{Descriptive Statistics of Dependent Variable}

Table 2 shows the descriptive statistics for total risk-related sentences and the sentences frequency in 94 Jordanian firms' annual reports over 2014-2017. All risk-related sentences are categorized through one of six risk categories and computed as shown in Table 2. The total number of risk disclosure sentences is 10660 sentences in all annual reports of Jordanian firms. Total of risk disclosure sentences to each firm ranges from a minimum value of 2 sentences to a maximum value of 61 sentences and the mean of RD is 28 sentences. The average is relatively similar to averages of 20, 28, 20, 26, 28 sentences found by Amran et al. (2009), Elzahar and Hussainey (2012), Al-Shammari (2014), Mokhtar and Mellett (2013) and Moumen et al. (2016) respectively. 
INTERNATIONAL JOURNAL OF ACADEMIC RESEARCH IN ACCOUNTING, FINANCE AND MANAGEMENT SCIENCES

Vol. 10, No. 3, 2020, E-ISSN: 2225-8329 @ 2020 HRMARS

\section{Table 2}

Descriptive Statistics of Risk Disclosure

\begin{tabular}{c|l|l|l|l|l|}
\hline Risk Disclosure & Sum & Mean & Min & Max & Percentage \\
\hline Financial Risk & 3090 & 8.218085 & 0 & 22 & $29 \%$ \\
Operation Risk & 2376 & 6.319149 & 0 & 14 & $22 \%$ \\
Empowerment Risk & 969 & 2.577128 & 0 & 10 & $9 \%$ \\
$\begin{array}{c}\text { Information Processing } \\
\text { and Technology Risk }\end{array}$ & 836 & 2.223404 & 0 & 14 & $8 \%$ \\
Integrity Risk & 1165 & 3.098404 & 0 & 11 & $11 \%$ \\
Strategic Risk & 2218 & 5.898936 & 0 & 20 & $21 \%$ \\
\hline Total Risk Disclosure & 10660 & 28.35106 & 2 & 61 & $100 \%$
\end{tabular}

Regarding independent variables, as shown in Table 3, the average firm size (SIZE) is 7.479, similar to Alsmady (2018), Siam et al. (2018) and Mardini et al. (2013) who found that the average size of Jordanian firms is 7.45, 7.217 and 7.90 respectively. The percentage of firms in the industrial sector (SECTR) is $52.13 \%$, which refers that more than half of Jordanian firms are industrial firms. The result is close to result of Al Daoud, Ismail and Lode (2014) who found that industrial sector is $46 \%$. In terms of audit firm type, Table 3 shows that the mean value of leverage (LEVER) in this study is $32.273 \%$, supported by Siam et al. (2018), Makhlouf et al. (2018) and Abu Qa'dan and Suwaidan (2018) with figures of $38.3 \%, 35 \%$ and $35.9 \%$, respectively. The mean value of company profitability in Jordanian firms is 1.947. As for the level of liquidity in Jordanian firms, as shown in Table 3, the average value of liquidity is 9.503 with minimum and maximum .01 and 934.2, respectively.

\section{Table 3}

Descriptive Statistics For Independent Variables

\begin{tabular}{lllllll|}
\hline Variable & Mean & Std.Dev. & Min & Max \\
\hline SIZE & 7.479 & .639 & 5.861 & 9.255 \\
SECTR & .521 & .5 & 0 & 1 \\
LEVER & 32.273 & 23.024 & 0 & 104 \\
PROFIT & 1.947 & 14.393 & -195 & 39 \\
LIQUID & 9.503 & 76.195 & .01 & 934.2 \\
\hline
\end{tabular}

\section{Regression Analysis Results}

Several tests have been conducted to verify the quality of the data panel before undertaking the regression analysis, namely, normality, outliers, linearity, multicollinearity, heteroscedasticity and autocorrelation. Multicollinearity is tested by the correlations matrix test. As shown in Table 4, the Pearson correlation coefficients among the independent variables are presented in Table 4. All variables have a correlation of less than 0.390 , which means there is no multicollinearity, because none of the variables correlates above 0.9 . Consequently, multicollinearity problem does not exist in this model. 
INTERNATIONAL JOURNAL OF ACADEMIC RESEARCH IN ACCOUNTING, FINANCE AND

MANAGEMENT SCIENCES

Vol. 10, No. 3, 2020, E-ISSN: 2225-8329 @ 2020 HRMARS

\section{Table 4}

Correlations matrix of study variables

\begin{tabular}{lllllll}
\hline Variables & $\mathbf{( 1 )}$ & $\mathbf{( 2 )}$ & $\mathbf{( 3 )}$ & $\mathbf{( 4 )}$ & $\mathbf{( 5 )}$ & $\mathbf{( 6 )}$ \\
\hline (1) CRD & 1.000 & & & & & \\
(2) SIZE & 0.300 & 1.000 & & & & \\
(3) SECTR & 0.202 & -0.120 & 1.000 & & & \\
(4) LEVER & 0.258 & 0.390 & 0.026 & 1.000 & & \\
(5) PROFIT & 0.059 & 0.065 & -0.070 & -0.158 & 1.000 & \\
(6) LIQUID & -0.230 & -0.225 & -0.095 & -0.146 & -0.019 & 1.000 \\
\hline
\end{tabular}

We used random effects regression model to examine the relationship between firm characteristics and corporate risk disclosure. Table 5 summarized the findings. As shown in Table 5, the model is statistically significant and fit at the $1 \%$ level with the $P$-value $=0.000, R^{2}=0.189$, which means 18.9 $\%$ percent of the variance of risk disclosure could be explained by independent variables.

\section{Table 5}

Multiple Regression Results

\begin{tabular}{llll}
\hline CRD & Coef. & t-value & p-value \\
\hline SIZE & 3.856 & 4.37 & 0.000 \\
SECTR & 4.675 & 4.59 & 0.000 \\
LEVER & 0.072 & 2.98 & 0.003 \\
PROF & 0.061 & 1.71 & 0.088 \\
LIQD & -0.019 & -2.74 & 0.006 \\
\hline Number of obs & 376.000 & \\
R-squared & 0.189 & \\
F-test & 17.252 & \\
Prob $>$ F & 0.000 &
\end{tabular}

The relationship between firm size (SIZE) and corporate risk disclosure (CRD) is significantly and positive $(t=4.37, p=0.000)$. These findings suggest that large firm provide more risk information in Jordanian companies. This result is consistent with Abraham and Cox (2007), Amran et al. (2009), AlShammari (2014), Konishi and Ali (2007), Mohobbot (2005) and Shrives and Linsley (2003) who revealed a positive connection between firm's size and risk disclosure. Table 5 shows a significant positive relationship between type of sector (SECTR) and corporate risk disclosure (CRD) ( $t=4.675, p$ $=0.000$ ), suggesting that firms in the industrial sector disclose more risk information than those in the service sector. This result is consistent with those reported by Cooke (1992) and Mangena and Pike (2005) who found a significant positive relationship between type of sector and corporate disclosure. Rajab and Handley-Schachler (2009) found that industry type was significantly and positively related to risk information disclosure.

Leverage of firms (LEVER) has a significant association with corporate risk disclosure (CRD) $(t=2.98$, $p=0.003)$. This result indicates that the firms with high level of leverage disclose more risk information. This result is similar to previous studies by Hassan (2009) and Taylor, Tower and Neilson (2010) who found a positive relationship between leverage and risk disclosure. Table 5 also presents that the relation between risk disclosure level and firm profitability (PROF) is statistically positive and significant ( $t=1.71, p=0.088$ ). This finding is consistent with result of Deumes and Knechel (2008) 
INTERNATIONAL JOURNAL OF ACADEMIC RESEARCH IN ACCOUNTING, FINANCE AND MANAGEMENT SCIENCES

Vol. 10, No. 3, 2020, E-ISSN: 2225-8329 ๑ 2020 HRMARS

and Mousa and Elamir (2013) who reported that firm profitability is positively related to risk disclosure. The results are in line with signalling theory indicating that firms that attain high profitability disclose more information to convey their present performance to the outside investors. Table 5 shows a negative significant relationship between liquidity (LIQD) and corporate risk disclosure (CRD) $(t=-2.74, p=0.006)$. These results are not consistent with the study's expectation that companies with high liquidity have more tendencies to disclose risk information.

\section{Conclusion}

This study aims to measure the level of risk disclosure and investigate the key factors that affect the level of risk disclosure as well. These factors are the firm attributes that include firm size, type of sector, leverage, profitability, and liquidity. To the best of the authors' knowledge, there are no previous studies in the Jordan context that investigate the relationship between firm characteristics and risk disclosure. Therefore, the contributions of this paper are. First, examining the risk information that become important items to the stakeholders to make an informed decision. Second, it investigates the relationship between firm characteristics and level of risk disclosure to recognise the potential effect of such characteristics on risk disclosure practices in the Jordanian environment. Content analysis method has been used to compute the number of risk-related sentences. The study used OLS regression models to test the hypothesis. it found that firm size, type of sector, leverage, and profitability significantly affect the risk information disclosed in Jordanian firms' annual reports. However, the rate of liquidity showed a negative effect on the level of risk disclosure.

Although the study has added more understanding to the relationship between firm characteristics and corporate risk disclosure practices, it has several limitations that can be addressed in future research. This study focuses on the effect of firm characteristics on corporate risk disclosure and ignored the important role of corporate governance mechanisms. Therefore, future empirical researches are advised to consider the corporate governance variables that are applied in the Jordanian environment. Also, the consequences of risk disclosure (e.g., cost of capital, analysts' forecast, firm value, and share prices) is a crucial topic, Further research could be conducted to investigate them.

\section{References}

Abraham, S., and Cox, P. (2007). Analysing the determinants of narrative risk information in UK FTSE 100 annual reports. The British Accounting Review, Vol. 39, pp. 227-248.

Ali, M. M., and Taylor, D. (2014). "Content analysis of corporate risk disclosure in Malaysia”, In 4th Annual International Conference on Accounting and Finance (AF 2014), (pp. 15-24).

Aljifri, K., and Hussainey, K. (2007). "The determinants of forward-looking information in annual reports of UAE companies". Managerial Auditing Journal, Vol. 22 No. 9, pp. 881-894.

Al-Shattarat, W. K., Haddad, A. E., and Al-hares, O. M. (2010). "The extent of voluntary disclosure in an emerging capital market: The case of Jordan". Journal of Modern Accounting and Auditing, Vol. 6 No. 10, pp. 39-51.

Amran, A., Bin, A., and Hassan, B. (2009). "Risk reporting: An exploratory study of risk management disclosure in Malaysian annual reports". Managerial Auditing Journal. Vol. 24 No 1, pp. 39-57.

Aryani, D. N., and Hussainey, K. (2017). "The determinants of risk disclosure in the Indonesian non-listed banks". Int. J. Trade and Global Markets, Vol. 10 No. 1, pp. 58-66.

Barako, D. G., Hancock, P., and Izan, H. Y. (2006). “Factors influencing voluntary corporate disclosure by Kenyan 
INTERNATIONAL JOURNAL OF ACADEMIC RESEARCH IN ACCOUNTING, FINANCE AND

MANAGEMENT SCIENCES

Vol. 10, No. 3, 2020, E-ISSN: 2225-8329 ๔ 2020 HRMARS

companies". Corporate Governance: An International Review, Vol. 14 No. 2, pp. 107-125.

Beretta, S., and Bozzolan, S. (2004). "A framework for the analysis of firm risk communication". The International Journal of Accounting, Vol. 39, pp. 265-288.

Cabedo, J. D., and Tirado, J. M. (2004). "The disclosure of risk in financial statements". Accounting Forum, Vol. 28 No. 2, pp. 181-200.

Chen, S., Chen, X., and Chengf, Q. (2008). “Do family firms provide more or less voluntary disclosure?”. Journal of Accounting Research, Vol. 46 No. 3, pp. 499-536.

Cordazzo, M., Papa and Rossi, P. (2017). "The interaction between mandatory and voluntary risk disclosure: a comparative study". Managerial Auditing Journal, Vol. 32 No. 7, pp. 682-714.

Deumes, R., and Knechel, W. (2008). "Economic incentives for voluntary reporting on internal risk management and control systems". Auditing: A Journal of Practice \& Theory, Vol. 27 No. 1, pp. 35-66.

Elshandidy, T., Fraser, I., and Hussainey, K. (2013). "Aggregated, voluntary, and mandatory risk disclosure incentives: Evidence from UK FTSE all-share companies". International Review of Financial Analysis, Vol. 30, pp. 320-333.

Elzahar, H., and Hussainey, K. (2012). "Determinants of narrative risk disclosures in UK interim reports". The Journal of Risk Finance, Vol. 13 No. 2, pp. 133-147.

Eng, L. L., and Mak, Y. T. (2003). “Corporate governance and voluntary disclosure”. Journal of accounting and public policy, Vol. 22 No. 4, pp. 325-345.

Hassan, M. (2009). "UAE corporations-specific characteristics and level of risk disclosure”. Managerial Auditing Journal, Vol. 24 No. 7, pp. 668-687.

Ho, S. S. M., and Wong, K. S. (2001). "A study of the relationship between corporate governance structures and the extent of voluntary disclosure". Journal of International Accounting, Auditing \& Taxation, Vol. 10, pp. 139-156.

Ivers, M. (1991). The random house guide to good writing, New York: Random House. Jensen.

Jensen, M. C., and Meckling, W. H. (1976). "Theory of the firm: Managerial behavior, agency costs and ownership structure". Journal of financial economics, Vol. 3 No. 4, pp. 305-360.

Khlif, H., and Hussainey, K. (2016). "The association between risk disclosure and firm characteristics: A metaanalysis". Journal of Risk Research, Vol. 19 No. 2, pp. 181-211.

Konishi, N., and Ali, M. M. (2007). "Risk reporting of Japanese companies and its association with corporate characteristics". International Journal of Accounting, Auditing and Performance Evaluation, Vol. 4 No. 3, pp. 263-285.

Lajili, K. (2009). "Corporate risk disclosure and corporate governance". Journal of Risk and Financial Management, Vol. 2 No. 1, pp. 94-117.

Linsley, P. M., and Shrives, P. J.(2003). “Risk reporting by German and UK companies: hot air or meaningful disclosure". Paper presented at Financial Reporting and Business Communication conference, Cardiff, United Kingdom.

Linsley, P. M., and Shrives, P. J. (2006). "Risk reporting: A study of risk disclosures in the annual reports of UK companies". British Accounting Review, Vol. 38 No. 4, pp. 387-404.

Mangena, M., and Pike, R. (2005). "The effect of audit committee shareholding, financial expertise and size on interim financial disclosures". Accounting and Business Research, Vol. 35 No. 4, pp. 327-349.

Milne, M. J., and Adler, R. W. (1999). "Exploring the reliability of social and environmental disclosures content analysis". Accounting, Auditing \& Accountability Journal, Vol. 12 No. 2, pp. 237-256.

Mohobbot, A. (2005). "Corporate risk reporting practices in annual reports of Japanese companies". Japanese Journal of Accounting, Vol. 16 No. 1, pp. 113-133. 
INTERNATIONAL JOURNAL OF ACADEMIC RESEARCH IN ACCOUNTING, FINANCE AND

MANAGEMENT SCIENCES

Vol. 10, No. 3, 2020, E-ISSN: 2225-8329 @ 2020 HRMARS

Mokhtar, E. S., and Mellett, H. (2013). "Competition, corporate governance, ownership structure and risk reporting". Managerial Auditing Journal, Vol. 28 No. 9, pp. 838-865.

Moumen, N., Othman, H. B., and Hussainey, K. (2015). "The value relevance of risk disclosure in annual reports: Evidence from MENA emerging markets". Research in International Business and Finance, Vol. 34, pp. 177-204.

Moumen, N., Ben Othman, H., and Hussainey, K. (2016). "Board structure and the in formativeness of risk disclosure: Evidence from MENA emerging markets". Advances in Accounting, Vol. 35, pp. 82-97.

Nahar, S., Azim, M., and Jubb, C. (2016). "The determinants of risk disclosure by banking institutions: Evidence from Bangladesh". Asian Review of Accounting, Vol. 24 No. 4, pp. 426-444.

Naser, K., Al-Khatib, K., and Karbhari, Y. (2002). "Empirical evidence on the depth of corporate information disclosure in developing countries: The case of Jordan". International journal of commerce and management, Vol. 12 No. (3/4), pp. 122-155.

Ntim, C. G., Lindop, S., and Thomas, D. A. (2013). "Corporate governance and risk reporting in South Africa: A study of corporate risk disclosures in the pre-and post-2007/2008 global financial crisis periods". International Review of Financial Analysis, Vol. 30, pp. 363-383.

Oliveira, J., Lucia, R., and Craig, R. (2011). "Voluntary risk reporting to enhance institutional and organizational legitimacy Evidence from Portuguese banks". Journal of Financial Regulation and Compliance, Vol. 19 No. 3, pp. 271-288.

Rajab, B., and Handley-Schachler, M. (2009). "Corporate risk disclosure by UK firms: trends and determinants". World Review of Entrepreneurship, Management and Sustainable Development, Vol. 5 No. 3, pp. 224243.

Chrand, C., and Elliott, J. (1998), "Risk and financial reporting: a summary of the discussion at the 1997 AAA/FASB Conference", Accounting Horizons, Vol. 12 No. 3, pp. 271-82.

Taylor, G., Tower, G., and Neilson, J. (2010). "Corporate communication of financial risk". Accounting and Finance, Vol. 50 No. 2, pp. 417-446.

Uddin, M. H., and Hassan, M. K. (2011). "Corporate risk information in annual reports and stock price behavior in the United Arab Emirates". Academy of Accounting and Financial Studies, Vol. 15 No. 1, pp. 59-84.

Watts, R. L., and Zimmerman, J. L. (1986). "Positive accounting theory”. London, Prentice-Hall.

Appendix A

Risk disclosure categories adopted from Linsley and Shrives (2006)

\section{Financial risk}

- Interest rate

- Exchange rate

- Commodity

- Liquidity

- Credit 


\section{Operations Risk}

- Customer Satisfaction

- Product Development

- Efficiency and Performance

- Sourcing

- Stock Obsolescence and Shrinkage

- Product and Service Failure

- Environmental

- Health and Safety

- Brand Name Erosion

\section{Empowerment Risk}

- Leadership And Management

- Outsourcing

- Performance Incentives

- Change Readiness

- Communications

Information Processing and Technology Risk

- Integrity

- Access

- Availability

- Infrastructure

Integrity Risk

- Management and Employee Fraud

- Illegal Acts

- Reputation

Strategic Risk

- Environmental Scan

- Industry

- Business Portfolio

- Competitors

- Pricing

- Valuation

- Planning

- Life Cycle

- Performance Measurement

- Regulatory, Sovereign and Political

Appendix B

Decision rules for risk disclosures

To identify risk disclosures a broad definition of risk is to be adopted as explained below. 
Vol. 10, No. 3, 2020, E-ISSN: $2225-8329$ @ 2020 HRMARS

- Sentences are to be coded as risk disclosures if the reader is informed of any opportunity or prospect, or of any hazard, danger, harm, threat or exposure, that has already impacted upon the company or may impact upon the company in the future or of the management of any such opportunity, prospect, hazard, harm, threat or exposure.

- Although the definition of risk is broad, disclosures must be specifically stated; they cannot be implied.

- The risk disclosures shall be classified into the categories in the Appendix A.

- If a sentence has more than one possible classification, the information will be classified into the category that is most emphasised within the sentence.

- Any disclosure that is repeated shall be recorded as a risk disclosure sentence each time it is discussed. If a disclosure is too vague in its reference to risk, then it shall not be recorded as a risk disclosure. 